\title{
DEFORESTATION IN PERU AND STRATEGIC PLAN FOR ITS REDUCE AMAZONIAN FORESTS
}

Vicenta Irene Tafur Anzualdo Univesity National University Federico Villarreal UNFV, Lima, (Peru).

E-mail:vtafur@unfv.edu.pe

ORCID: https://orcid.org/0000-0002-1888-7848

Doris Esenarro

Federico Villarreal University EUPG- UNFV- Lima, (Peru). Specialized Institute for Ecosystems and Natural Resources Research (INERN), (Peru)

E-mail: desenarro@unfv.edu.pe

ORCID: https://orcid.org/0000-0002-7186-9614

Rogelia Guillen

Univesity National University Federico Villarreal UNFV, (Peru).

E-mail: rguillen@unfv.edu.pe

ORCID: https://orcid.org/0000-0001-9123-0124

Samuel Reyna

Univesity National University Federico Villarreal UNFV, (Peru).

E-mail: sreynam@unfvedu.pe ORCID: : https://orcid.org/ 0000-0002-8133-1711

Recepción: 03/09/2021 Aceptación: 01/11/2021 Publicación: 14/02/2022

\section{Citación sugerida:}

Tafur, V. I., Esenarro, D., Guillen, R., y Reyna, S. (2022). Deforestation in Peru and strategic plan for its reduce Amazonian forests. 3C Tecnología. Glosas de innovación aplicadas a la pyme, Edición Especial, (febrero 2022), 97-111. https://doi.org/10.17993/3ctecno.2022.specialissue9.97-111 


\section{ABSTRACT}

The present research aims to evaluate deforestation and strategies to reduce the deterioration of Amazonian forests. Peru has a considerable area of forest cover, by the year 2020 during the pandemic the Peruvian Amazon suffered a significant loss of forest cover due to deforestation, which aggravates floods, droughts and landslides, products of climate change, the expansion of agriculture and livestock, mining, road construction and population growth, among others, are activities that promote deforestation. The technique used is the bibliographic review of different documents produced in public and private institutions related to the subject, also the Joint Declaration of Intent (DCI) is a scheme of economic incentives to combat deforestation and forest degradation, which has the cooperation of Peru, Norway, and Germany, which was raised in three phases: Phase I: Preparation; Phase II: Transformation and Phase III: Payment for results; in October 2018 the implementation plan of Phase II was completed. The agreement that has been extended until 2025.

\section{KEYWORDS}

Deforestation, Land use change, Amazon, Joint Declaration of Intent. 


\section{INTRODUCTION}

Peru ranks tenth in the world in terms of area covered by forests, with the jungle region accounting for $90 \%$ of this forest area. It is estimated that about 330,000 inhabitants of the country depend directly on forests for their livelihoods through their multiple products and ecosystem services (Smith \& Schwartz, 2015; Galarza \& La Serna, 2016).

Traditionally, forests have been taken as a source of income from timber production (Unión Internacional para la Conservación de la Naturaleza (UICN), 2018), in addition to the use of non-timber products, biodiversity, ecotourism, and environmental services (Galarza \& La Serna 2016), whose economic potential is growing for Peru, to such an extent that the contribution of the forestry sector to the Gross Domestic Product (GDP), which for many years has remained at $1 \%$, could increase to $8 \%$ if more attention were paid to the exploitation of non-timber products such as fruits, stems, and medicinal plants, in addition to encouraging ecotourism.

This is without considering the biodiversity present in natural protected areas that, according to MINAM (Ministerio de Ambiente (MINAM), 2021), extend over 20 million hectares of forests and other ecosystems and contribute more than US\$1 billion annually due to nontimber forest products scenic beauties, etc. This could point to the forestry sector is one of the most significant potential for economic development (Galarza \& La Serna, 2016). However, the Peruvian Ministry of Environment warns that, by 2020 at the height of the pandemic, the Peruvian Amazon lost more than 150000 ha of forest due to the massive return of migrants to their community (Ministerio de Ambiente (MINAM), 2021).

In tropical countries, including our own, the most important cause of forest cover reduction is the expansion of agriculture and livestock (Ministerio de Ambiente (MINAM), 2016). This deforestation due to land-use change is complemented by the development of extractive industries, road construction, and the growth and creation of towns (Ministerio de Ambiente (MINAM), 2016; Smith \& Schwartz 2015; Vargas et al., 2020).

Faced with this scenario, Peru has joined efforts with Germany and Norway through the Joint Declaration of Intent (JIU) to combat deforestation and forest degradation in order to reduce greenhouse gas emissions. 
In this article, the link between deforestation and human, economic and environmental components is presented and the actions being carried out to combat deforestation and forest degradation in our country.

\section{MATERIALS AND METHODS}

The analysis of the loss of vegetation cover in the Peruvian Amazon forests and the fight against forest degradation is fundamental, so we must determine the loss of forest in the coming years if we continue with the same problems that cause the loss of the Amazon forests. For this, we use a simple linear regression equation to project future Amazon forest loss.

$$
\widehat{Y}=\mathrm{A}+\beta(\mathrm{X})
$$

Where: $\hat{y}$ ependent variable, A ordinate of origin, $\beta$ slope of the line and $\mathrm{X}$ independent variable.

The study area is the humid forests of the Peruvian Amazon, in the departments of Loreto, Ucayali, San Martin, Huanuco, Madre de Dios, Junin, Cuzco, Puno, Amazonas, and Pasco areas of significant deforestation and soil degradation.

The statistical data comes from institutional platforms and reports from secondary sources such as the National Institute of Statistics and Informatics (INEI), the Ministry of Agrarian Development and Irrigation (MIDAGRI) and the Ministry of Environment (MINAM), indexed magazines, books, and information published by private institutions linked to forestry, agriculture and the environment. The bibliographic sources for the capture of data on deforestation in the Amazonian forests during the study period were the institutions mentioned above.

Deforestation rate for the calculation of the annual deforestation rate was obtained from historical data that allowed the analysis in the period 2001-2019, with the following equation:

$$
D=\left(\frac{D F-D I}{D I}\right) 100
$$

Where: D is the deforestation rate; DF is the area deforested in the final year (2019), and DI is the area deforested in the initial year (2001). 


\section{RESULTS}

\subsection{DEFORESTATION IN THE AMAZON FORESTS}

The deforested areas of Amazonian forests in Peru, period 2001-2019, amount to 2433 314 hectares; the annual average is 128069 hectares (Ministerio de Agricultura y Riego, Ministerio de Ambiente, Servicio Nacional Forestal (SERFOR) \& BOSQUES, 2017).

Amazon forests face intense pressures with high trends, as evidenced in Table and Figure 1, the highest levels of deforestation $(62.36 \%$ ) were carried out in the last ten years. As can be seen in the Table above, the surfaces and percentages in ascending and continuous growth of deforestation. The leading causes of deforestation are agriculture, cattle ranching, the opening of road infrastructure, access to waterways, and small timber extractors, among others (Servicio Nacional Forestal (SERFOR), 2015).

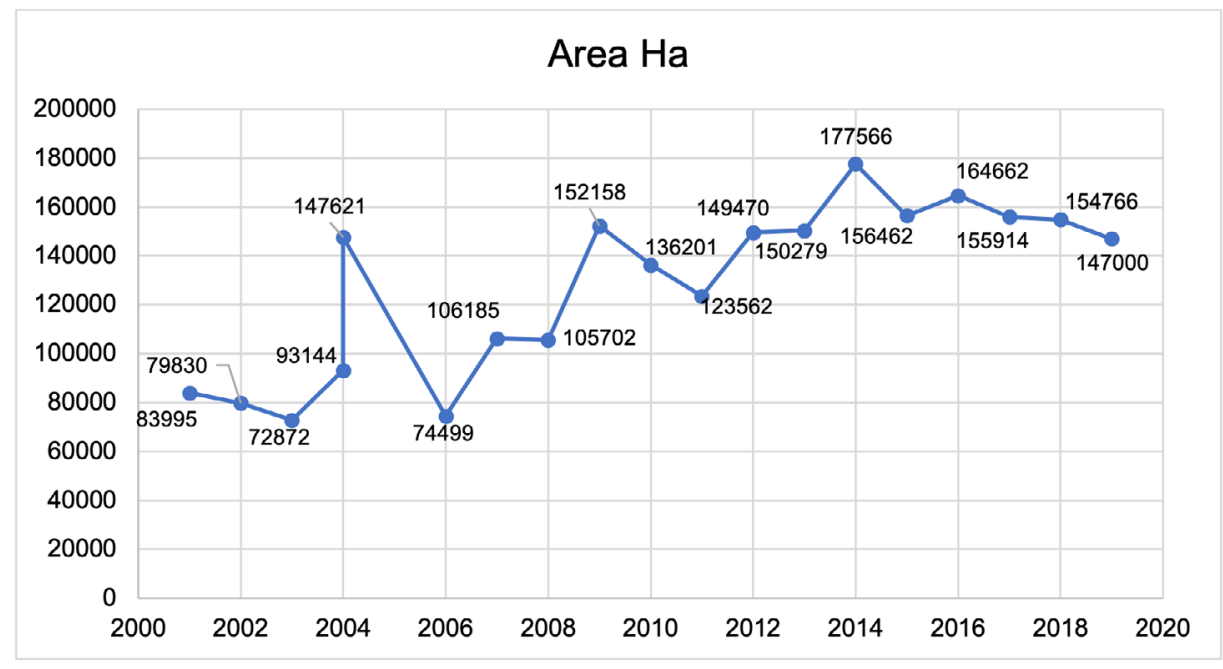

Figure 1. Deforested areas in the period $2001-2019$.

Source: own elaboration.

The direct and indirect causes of the deforested areas of the Amazon forests are in the expansion of small, medium and large-scale agriculture 51.6\%, legal mining 5.8\%, expansion of communication infrastructure and extractive industries $0.3 \%$, small and large-scale cattle ranching 39.9\% coca cultivation 2.3\% (BOSQUES, 2016).

If we continue with the activities described in the previous paragraph, the loss of forests will increase, causing greater socio-environmental problems and biodiversity loss. With the 
statistical data for the period 2007-2019, the deforested areas for 2020, 2021, and 2022 can be determined with a simple linear regression equation, this, we have previously considered meeting two of the conditions of being numerical and having a normal distribution of the data set:

$$
\widehat{Y}=\mathrm{A}+\beta(\mathrm{X})
$$

Area $(\mathrm{Y})=$ Constant $(\mathrm{A})+$ Slope of the line $(\beta)$ Independent variable $(\mathrm{X})$

$\mathrm{Y}=118062,962+3808,071 \mathrm{X}$

$\mathrm{Y}_{20}=118062,962+3808,071(14)=171376$

$\mathrm{Y}_{21}=118062,962+3808,071(15)=175184$

$\mathrm{Y}_{22}=118062,962+3808,071(16)=178992$

According to the results obtained in 2020, 2021 and 2022, approximately 171,376, 175,184 and 178,992 hectares would be deforested, respectively, degraded areas that would be used for agriculture and cattle ranching. However, this reality can be reduced simply by complying with the Joint Declaration of Intent (JIU), the cooperation agreement between the governments of Peru, Norway, and Germany that has strategic objectives to contribute to the reduction of greenhouse gas emissions produced by deforestation and forest degradation, sustainable agricultural and forestry development and environmentally sound mining. Agreement that seeks to strengthen the implementation of the United Nations Framework Convention on Climate Change and the national strategy on forests and climate change to reduce forest loss in the Amazon and contribute to sustainable development in Peru (Ministerio de Ambiente (MINAM), 2014).

The deforested areas of Tropical Rainforests, by the department in 2019, amount to 148 426 hectares, equivalent to 200 thousand soccer fields (Sierra, 2018). The departments of Ucayali, Madre de Dios, Huánuco, and Loreto, concentrate approximately 67\% of deforested areas. However, the departments of Ayacucho and Cajamarca lost only 1.18 $\%$ and $0.82 \%$ of their tropical rainforest of the total deforested regions of the same year. 
Table 1. Deforested areas by department 2019.

\begin{tabular}{|c|c|c|c|c|c|c|c|}
\hline APARTMENTS & FOREST & 2018 & $\%$ & 2019 & $\%$ & TO 2019 & $\%$ \\
\hline Amazonas & 2831731 & 7453 & 4.82 & 5805 & 3.91 & 94084 & 3.87 \\
\hline Ayacucho & 209922 & 1744 & 1.13 & 2166 & 1.46 & 17517 & 0.72 \\
\hline Cajamarca & 346762 & 1276 & 0.82 & 600 & 0.40 & 19275 & 0.79 \\
\hline Cusco & 3063940 & 9643 & 6.23 & 7103 & 4.79 & 90543 & 3.72 \\
\hline Huancavelica & 17299 & 18 & 0.01 & 92 & 0.06 & 1105 & 0.05 \\
\hline Huánuco & 1545972 & 16560 & 10.70 & 14956 & 10.08 & 333880 & 13.72 \\
\hline Junín & 1850889 & 8497 & 5.49 & 13960 & 9.41 & 165201 & 6.79 \\
\hline La Libertad & 68228 & 142 & 0.09 & 37 & 0.03 & 1112 & 0.05 \\
\hline Loreto & 35047942 & 26203 & 16.93 & 23140 & 15.59 & 453420 & 18.63 \\
\hline Madre de Dios & 7905744 & 23492 & 15.18 & 21378 & 14.40 & 231111 & 9.50 \\
\hline Pasco & 1388278 & 5610 & 3.62 & 6035 & 4.07 & 115344 & 4.74 \\
\hline Piura & 41492 & 60 & 0.04 & 26 & 0.02 & 3316 & 0.14 \\
\hline Puno & 1423073 & 6701 & 4.33 & 3716 & 2.50 & 37010 & 1.52 \\
\hline San Martín & 3344540 & 21376 & 13.81 & 11034 & 7.43 & 447546 & 18.39 \\
\hline Ucayali & 9336773 & 25991 & 16.79 & 38377 & 25.86 & 422851 & 17.38 \\
\hline Total & 68422585 & 154766 & 100 & 148426 & 100 & 2433315 & 100 \\
\hline
\end{tabular}

Source: own elaboration.

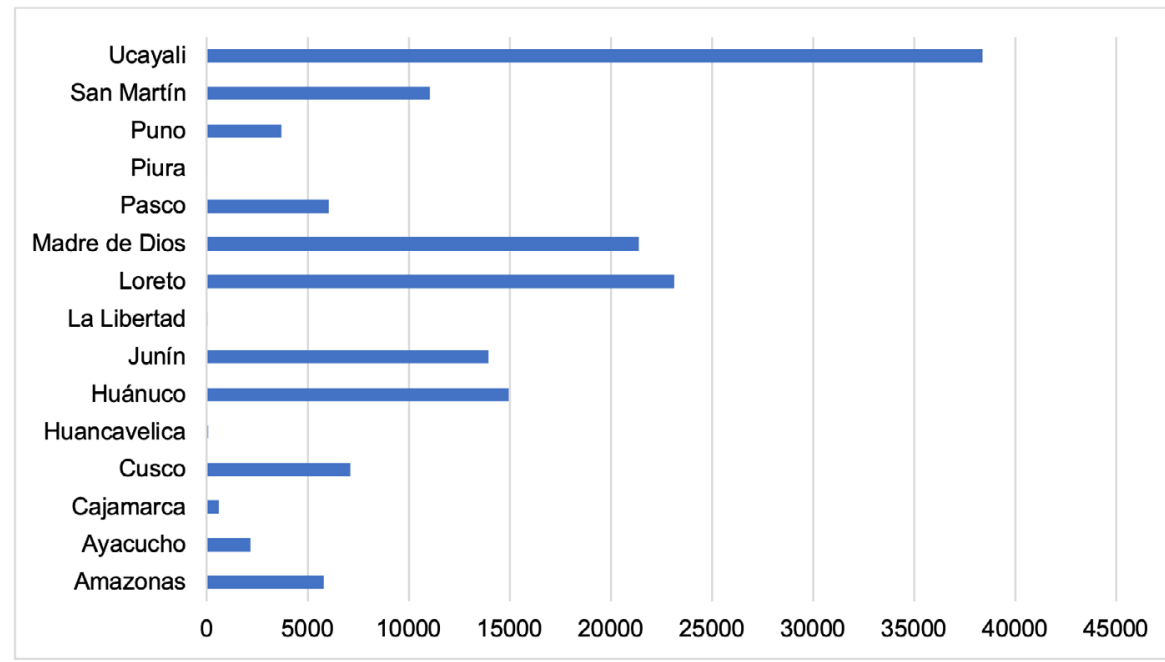

Figure 2. Deforested areas by department 2019.

Source: own elaboration. 
One of the causes of deforestation and loss of Amazonian forests is agriculture and cattle ranching for the production of bread crops, rice, corn, cocoa, papaya, coffee and other products in order to serve the domestic and foreign markets. In 2017, a total of 16220 hectares were deforested for the activities above. In the Interoceánica area, 11115 hectares have been deforested for gold mining and agricultural activity, likewise, in the Iberia sector, 3220 hectares were deforested for agricultural activity. In the last months of 2017 in the border of the departments of San Martin and Loreto 750 hectares have been deforested for oil palm production of a large-scale agricultural project and in the Amazonas region, along the Bagua-Saramiriza road 1135 hectares have been deforested for agriculture and cattle ranching (Sierra, 2018).

\subsection{IMPACTS OF DEFORESTATION}

Deforestation brings the invasion and illegal appropriation of land by farmers, miners, or loggers, displacement of indigenous populations, conflicts linked to access of forest resources, and loss of knowledge and cultural values. It strengthens climate change affecting surrounding populations and society through increased floods, droughts, and huaycos.

The location of deforestation depends on geographical, political, and economic variables. In Madre de Dios, the construction of the Interoceanic Highway has allowed the migration of poor people to environmentally fragile and isolated areas. Currently, there is evidence of the disproportionate growth of illegal gold mining that devastates forests and contaminates water with mercury and other toxics (Smith \& Schwartz, 2015).

Illegal logging, which requires low investments for its implementation, impacts the wellbeing of the populations due to the selective loss of the most valuable species, greater inequity in income distribution, and, mainly, by developing an informal parallel economy that discourages private investment in long-term forest management, generating economic mechanisms of corruption. In coca-growing areas of the country, which occupy 43,900 ha with this crop, drug trafficking also does its thing by dumping chemicals used for coca leaf processing.

Deforestation involves the permanent loss of forest cover and its transformation into another land use. It affects the quantity and quality of water and on its courses that become 
more prone to cause flooding due to land degradation. By reducing the potential of the soil, the provision of food, other goods, and services is aggravated, deepening poverty and extreme poverty, marginalization, migration, and inequity, and the loss of biodiversity. This change in land use generates more significant greenhouse gas emissions due to the loss of an important carbon sink through deforestation, thus contributing to the worsening of the impacts of climate change and increasing the vulnerability of populations to extreme meteorological phenomena.

Pendrill et al. (2019) infer that deforestation of tropical forests is one of the most important sources of anthropogenic greenhouse gas emissions and carbon dioxide release, driven largely by the expansion of the agricultural, forestry and, the growing demand for agricultural products abroad, and the population explosion in all countries. In the period 2000-2016 GHG emissions from the Land Use, Land Use Change and Forestry (LULUCF) sector averaged 88.8 MTCO2e/year. In 2016 the Sector emissions were 112.88 MtCO2e of GHG emissions. Of this, $89 \%$ is due to the change of forest use to another activity, i.e. deforestation in the mentioned period has been the main cause of emissions (Vásquez, 2019).

\subsection{STRATEGIC PLAN TO COMBAT DEFORESTATION}

MINAM (2018) mentions that the Joint Declaration of Intent (JIU), signed by Germany, Norway, and Peru, is a scheme of financial incentives on the progress and fulfillment of deliverables or goals divided into three Phases: I) preparation (2015-2017), II) transformation (2017-2020) and III) payment for results (2016-2020). We are currently in Phase II of the ICD, whose strategies to reduce deforestation of Amazonian forests are: avoid through the cessation of permits, the change of land use from forest to agricultural services; evaluate the impact of timber harvesting, mining, agriculture, and infrastructure activities due to deforestation and forest degradation; reduce the remaining area of uncategorized forests by $50 \%$; increase the titling of native communities by 5 million hectares; involve at least 2 million hectares in the payment for conservation results of native communities; as well as implement projects of the Forestry Investment Program (MINAM 2018). However, due to the global Covid-19 pandemic, applications have been delayed, redirecting the limited 
public budget to address the health crisis, and therefore justifying the extension of the DCI (Bodo, Gimah, \& Seomoni, 2021).

On the last day of May, MINAM (2021) reiterated the commitment established in the DCI through an ADDENDUM; this agreement has been extended, renewed, and reinforced with a new partner, the Government of the United Kingdom of Great Britain and the United States as an observer, to reduce and end the loss of forests.

In addition, MINAM's Institutional Policy Framework (2019) confirms the reduction of deforestation and forest degradation using the policy instruments of the National Strategy on Forests and Climate Change (ENBCC), proposing as a vision "for the year 2030 the reduction of GHG emissions associated with the Land Use sector, Land Use Change and Forestry (USCUSS) and the vulnerability of the forest landscape and the population that depends on them, ensuring respect for the rights of citizens, especially indigenous peoples and rural populations linked to forests, with a territorial, intercultural and gender approach, in a context of adequate governance, productivity, competitiveness and valuation of forest ecosystems". The NBSAP establishes strategic actions such as sustainable agriculture and livestock, increasing the value of forests, reducing illegal/informal activities, reducing negative impacts of economic activities, zoning and forest management/granting of rights, monitoring impacts and effects of climate change, the resilience of forest ecosystems and reducing local vulnerability to achieve the objective of reducing Greenhouse Gas (GHG) emissions in the USCUSS sector (Leite-Filho et al., 2021).

\section{DISCUSSION}

Deforestation is the permanent loss of Amazonian forest cover, replacing forested soil areas for agricultural and livestock use. The effects on soil quality cause land degradation, as it is not suitable for these activities, decreasing soil quality, lowering the productivity of food, other goods, and services, exacerbating poverty, and the loss of biodiversity. This change in land use generates more significant greenhouse gas emissions due to the loss of an important carbon sink through deforestation and soil degradation, thus contributing to the worsening of the impacts of climate change and increasing the vulnerability of populations to extreme meteorological phenomena. 


\section{CONCLUSIONS}

Deforestation causes loss of forest areas, invasions and illegal land appropriation by farmers, cattle ranchers, immigrants, miners, loggers, displacement of indigenous populations, social conflicts and loss of knowledge and cultural values.

GHG emissions from the Land Use, Land Use Change, and Forestry sector averaged 88.8 MTCO2e/year.

The conservation of forests and the reduction of deforestation and degradation of these require coordinated work efforts in a multisectoral manner, in that sense, the activities that are being developed in the public institutions involved in the DCI must be fulfilled with the milestones and goals to be achieved by 2020 in favor of the Amazon to achieve the longedfor sustainable development of our country (Amaya et al., 2020).

The DCI has been extended, renewed and strengthened until 2025 with a new partner, the Government of the United Kingdom of Great Britain, with the purpose of reducing and ending the loss of Amazon forests and promoting sustainable development.

\section{REFERENCES}

Amaya, P. M., Esenarro, D., Rodriguez, C., Vega, V., \& López, J. (2020). Economic valuation of environmental attributes of the Yanachaga-Chemillén National Park via contingent valuation and choice experiment. World fournal of Engineering, 18(4), 558-565. https://www.emerald.com/insight/content/doi/10.1108/WJE-09-20200407/full/html

Bodo, T., Gimah, B., \& Seomoni, K. J. (2021). Deforestation: Human Causes, Consequences and Possible Solution. Journal of Geographical Research, 4. https://ojs. bilpublishing.com/index.php/jgr/article/view/3059

BOSQUES. (2016). Estrategia Nacional Sobre bosques y cambio climático. http:/ / www.bosques. gob.pe/archivo/ff3f54_ESTRATEGIACAMBIOCLIMATICO2016_ok.pdf 
Galarza, E., \& La Serna, K. (2016). Las concesiones forestales en el Perú: ¿cómo hacerlas sostenibles? Universidad del Pacífico. http://infobosques.com/portal/wp-content/ uploads/2016/03/per1.pdf

Inforegión. (2021). Alertan que la deforestación de bosques peruanos aumentaría en el 2021. ElMINAM estima que cifra superaría las 150 mil hectáreas durante el 2020. https:/ /www.inforegion. pe/281544/alertan-que-la-deforestacion-de-bosques-peruanos-aumentaria-enel-2021/

Instituto Nacional de Estadistica e Informatica (INEI). (2020). Anuario de Estadísticas ambientales. $\quad$ https://www.inei.gob.pe/media/MenuRecursivo/publicaciones_ digitales/Est/Lib1760/libro.pdf

Leite-Filho, A.T., Soares-Filho, B.S., Davis, J.L., Medeiros, G., \& Börner, J. (2021). Deforestation reduces rainfall and agricultural revenues in the Brazilian Amazon. Nature Communications, 12, 2591. https://doi.org/10.1038/s41467-021-22840-7

\section{Ministerio de Agricultura y Riego, Ministerio de Ambiente, Servicio Nacional} Forestal (SERFOR) \& BOSQUES. (2017). Cobertura y Deforestación en los Bosques Húmedos Amazónicos. https://cdn.www.gob.pe/uploads/document/file/263082/ Cobertura_y_Deforestacion_en_los_Bosques_Humedos_Amazonicos_al_2017.pdf

Ministerio de Ambiente (MINAM). (2014). Declaración Conjunta de Intensión. http: / /www. bosques.gob.pe/declaracion-conjunta-de-intencion

Ministerio de Ambiente (MINAM). (2016). El Perú y el Cambio Climático. Tercera Comunicación Nacional del Perú.

Ministerio de Ambiente (MINAM). (2019). Reporte de cumplimiento de la declaración conjunta de intención sobre REDD+ suscrita entre los gobiernos de Perú, Noruega y Alemania al 2018. https://www.minam.gob.pe/cambioclimatico/wp-content/uploads/ sites / 127/2019/10/190709-Reporte-DGI-2018_VF.pdf

Ministerio de Ambiente (MINAM). (2021a). Agenda $\mathcal{N}^{\circ} 1$ de la Declaración Conjunta de Intensión (DCI), entre el Gobierno de la República del Perú, el Gobierno de la República Federal 
de Alemania, el Gobierno del Reyno de Noruega, y el Gobierno del Reyno Unido de Gran Bretaña e Irlanda del Norte.

Ministerio del Ambiente (MINAM). (2021b). El Perú, cuarto país con más bosques tropicales. http://www.minam.gob.pe/programa-bosques/el-peru-cuarto-pais-con-masbosques-tropicales/

\section{Pendrill, F., Persson, U. M., Godar,J., Kastner, T., Moran, D., Schmidt, S., \& Wood,} R. (2019). Agricultural and forestry trade drives large share of tropical deforestation emissions. Global Environmental Change, 56, 1-10. https://doi.org/10.1016/j. gloenvcha.2019.03.002

Servicio Nacional Forestal (SERFOR). (2015). Interpretación de la Dinámica de la Deforestación en el Perú y Lecciones Aprendidas para reducirlas, documento de trabajo. https:/ / www.serfor.gob.pe/wp-content/uploads/2016/03/Interpretacion-de-la-dinamicade-la-deforestacion-en-el-Peru-y-lecciones-aprendidas-para-reducirla-1.pdf

Sierra, Y. (2018). Deforestación en el Perú equivale a 200 mil campos de fútbol en el 2017. https:// es.mongabay.com/2018/02/deforestacion-en-el-peru-2017/

Smith, J., \& Schwartz, J. (2015). La deforestación en el Perú: Cómo las comunidades indígenas, agencias gubernamentales, organizaciones sin fines de lucro y negocios trabajan juntos para detener la tala de los bosques. WWF. https://d2ouvy59p0dg6k.cloudfront.net/downloads/la_ deforestacion_en_el_peru.pdf

Unión Internacional para la Conservación de la Naturaleza (UICN). (2018). Bosques y economía. Integrar los valores de los bosques en las políticas económicas, las finanzas y los mercados. https://www.iucn.org/es/regiones/am\%C3\%A9rica-del-sur/nuestrotrabajo/bosques/bosques-y-econom $\% \mathrm{C} 3 \% \mathrm{ADa}$

Vargas, Y., Puerta, R., Palomino, F., Esenarro, D., Rodriguez, C., \& Pandey, B. (2020). Low planting densities for early maturation of Mauritia flexuosa L.f. for the sustainable management of plantations in Alto Huallaga, Peru. World fournal of Engineering. https://www.researchgate.net/publication/350609814_Low_planting_ 
densities_for_early_maturation_of_Mauritia_flexuosa_for_the_sustainable_ management_of_plantations_in_Alto_Huallaga_Peru

Vásquez, R. P. (2019). Mejora en la gestión de infraestructura para evitar deforestación en la Amazonía. DAR. http://www.dar.org.pe/archivos/publicacion/Medida_de_Mitigacion_ NDG.pdf 
